\title{
The Development of Slovak-Hungarian Relations in 1939-1940 from a Soviet Aspect
}

\author{
István JANEK \\ Magyar Tudományos Akadémia, Bölcsészettudományi Központ, Történettudományi Intézet \\ Research Centre for the Humanities, Hungarian Academy of Sciences, Budapest, \\ Úri u. 53, 1014 Budapest, Hungary \\ janek.istvan@freemail.hu
}

After the German occupation of Prague in March 1939, Edvard Beneš withdrew his former resignation from presidency and, as a former president of the state and the president of the republic, sent telegrams to the politicians of the great powers with the request to condemn the German invasion of his country. ${ }^{1}$ As a consequence of the German advance, the state of Czecho-Slovakia was dissolved, the Germans established the Protectorate of Bohemia and Moravia, and also Slovakia declared her independence on 14 March 1939. ${ }^{2}$ Beneš could get, with recurring calls, several western states to condemn the German aggression but no serious steps were taken beyond the scope of diplomacy.

Germany sent a memorandum to the Soviet government on 16 and 17 March 1939 on the dissolution of Czechoslovakia. The Soviet diplomacy felt the gravity of the situation and set its apparatus in motion. On 18 March 1939, the Soviet Ministry of Foreign Affairs sent a document to the German ambassador in Moscow; they condemned the German steps in eight points and they declared that the Soviet government did not acknowledge either the Protectorate or the independence of Slovakia. ${ }^{3}$

The Soviet administration put the blame for the situation on France and England as they sacrificed the small states of South-Western Europe in order to direct Nazi Germany towards the Soviet Union. After the annexation of Austria and Czechoslovakia the USSR became more concerned about her own safety, and therefore she increased her diplomatic activity in Eastern Europe. ${ }^{4}$ Opening towards Slovakia seemed advisable now since their embassies in Vienna, Prague and later Warsaw closed or worked as consulates due to the German advance, which limited the possibilities to obtain information. They needed to feel the connections in Bratislava and Budapest.

The Soviet interest increased and their activity became more intense after the Ribbentrop-Molotov pact. ${ }^{5}$ On 31 August 1939, Molotov gave a speech in which he said that

1 Béla ZSELICKY, Kárpátalja a cseh és a szovjet politika érdekterében 1920-1945, Budapest 1998, 47.

2 Slovak Foreign Minister Ferdinand Durčaňský sent his letter to the Soviet government in which he asked to acknowledge the independence of Slovakia, on 16 March 1939. Soviet Commissar for Foreign Affairs Maxim Maximovich Litvinov left it unanswered. SNA, Slovenský národný archív (Slovak National Archives; hereinafter referred to only as SNA), fund Ministerstvo zahraničných věcí (Ministry of Foreign Affairs; hereinafter referred only as MZV), Politické zprávy (Political News; hereinafter referred only as PZ), Box No. 112, doc. no. 1/1939.

3 Edvard BENEŠ, Paměti. Od Mnichova k nové válce a novému vítězství, vol. 1947, Praha 1947, 438-440.

4 Attila SERES, Magyar revíziós törekvések és a Szovjet külpolitika, in: Levéltári Közlemények, 71, 2000, 1-2, 81.

5 Ribbentrop and Molotov signed a nonaggression treaty with a secret protocol on the partition of Poland and the designation of spheres of interest in Eastern Europe on 23 August 1939. The struggle of the two powers for hegemony entered a new phase. 
the USSR could not tolerate European affairs being solved without her participation. ${ }^{6}$ The young Slovak Republic appeared an ideal solution for the increase of Soviet influence.

Leading Slovak politicians evaluated the Ribbentrop-Molotov pact a 'historic turn' which would create a good setting for the development of German-Soviet solidarity. ${ }^{7}$ Slovak foreign minister Ferdinand Durčanský ${ }^{8}$ regarded the approach of the two great powers as a guarantee for the peaceful development of Slovakia. ${ }^{9}$ The USSR was no more the manifestation of destructive forces for the Slovak administration. Jozef Tiso and his government had to revaluate their attitude to the Bolshevik regime: they gave up their total rejection and started to look at the USSR as a new ally of Germany. Parallel to this, also the USSR revaluated her viewpoint in connection with the dissolution of Czechoslovakia. The most remarkable element in the new Soviet paradigm was the recognition of the 'independent' Slovakia and the establishment of diplomatic connections with her. The Slovak Ministry of Foreign Affairs, realising the fundamental change in the relationship between the two great powers, decided almost immediately to establish connections with the Soviet Union. As a response to the Slovak initiative, the Soviet ambassador to Berlin, Aleksei Shkvartsev, told his colleague there, Matúš Cernák, that his government was open to establish diplomatic connections with Slovakia. ${ }^{10}$ This was implemented in early September 1939. The quickness of this step shows that it took place with the prompt approval of Vyacheslav Mikhailovich Molotov and losif Vissarionovich Stalin. Georgy Maksimovich Pushkin ${ }^{11}$ and Fraňo Tiso ${ }^{12}$, the nephew of Jozef Tiso, were appointed ambassadors to Bratislava and Moscow respectively. ${ }^{13}$

The fact that the USSR had become an unexpected ally of Slovakia was reflected in the press: "Russia has stood with all her inexhaustible power and weight on the side of Germany." a Bratislava paper wrote. ${ }^{14}$ This was a big surprise for the Slovakian public, after the previous articles had condemned the Soviet Union, which brought a swift change and

6 Valentina Vladimirovna MARIJNOVÁ, Brána na Balkán. Slovensko v geopolitických plánech SSSR a Německa v letech 1939-41, in: Soudobé dějiny, 1, 1994, 6, 830.

7 Slovák, 1939, Year 21, No. 234, 11 October, 1.

8 Ferdinand Ďurčanský (1906-1974): Slovak politician, lawyer. Deputy of the Slovak People's Party in the National Assembly from 1935. Editor of the periodical Nástup. From 7 October 1938 to 9 March 1939, minister in the autonomous government of Tiso. After the proclamation of the independence of Slovakia, he was a foreign minister until 1940. He did not hold any important offices afterwards. In 1945, he emigrated to the west, while sentenced to death at home. He was one of the leaders of Slovak emigration until his death.

9 Pavel MIČIANIK, Geopolitické postavenie Slovenska v rokoch 1939-1941, in: Politické vedy, 6, $2003,2,14$.

10 MARIJNOVÁ, 830.

11 Georgy Maximovich Pushkin (1909-1963): Soviet diplomat. Between 1939 and 1941, Soviet ambassador to Slovakia. In 1942, Head of the $3^{\text {rd }}$ European Department at the Foreign Commissary. In 1944-1948, advisor to the Allied Control Committee in Hungary. From 1945-1948, Soviet minister (envoy) to Hungary, from 1948-1949 ambassador. In 1959-1963, deputy foreign minister. In 1954-1958, Soviet ambassador to the GDR.

12 Fraňo Tiso (1894-1974): secondary school teacher, later bank manager. From March 1940 to May 1941, Slovak ambassador to the USSR. He emigrated to Canada in 1945. The Germans regarded Fraňo Tiso as a Pan-Slav, anti-German politician. See Milan Stanislav ĎURICA, Dejiny Slovenska a Slovákov v chronologickom prehl'ade, Bratislava 1995, 166.

13 Fraňo Tiso arrived in Moscow on 11 December 1939. However, Georgiy Maximovich Pushkin took his office in Bratislava only on 2 February 1940 (MIČIANIK, 14-15).

14 Slovenská politika, 1939, Year 20, No. 65, 24 October, 24. 
intensified economic connections as well.

Bratislava administration highly appreciated the new connections as the USSR could at least partially compensate for the losses after the severance of western connections. The Slovaks could expect no significant economic links with Western European countries at that time let alone confirmed political relations. The leaders in London and Paris shared the view that the birth of the Slovak state was the result of the German politicians' machinations, and therefore they were distrustful towards her, which was reflected in their policy. ${ }^{15}$ They limited diplomatic relations to a minimum. ${ }^{16}$ Soviet diplomats, on the other hand, characterised Slovakia as "a gate towards the Balkans" and "an eye" on the western half of Europe, and thus they thought it important for Moscow to be informed about the events that took place there. ${ }^{17}$

The Slovak press welcomed the establishment of diplomatic connections with great enthusiasm. The following text was published on 24 August 1939: "the close cooperation of the two states may bring the dream of the Slovaks close that all Slovaks beyond the borders could unite within one state." 18 The 'Slovenská politika' later wrote that the position of Slovakia would be further consolidated as the German protection was complimented by friendly relations with the USSR. According to the article the German-Soviet pact would have a consolidating effect on the international position of Slovakia and the Hungarians may even lose Subcarpathia. ${ }^{19}$ Slovakian journalists were given the instructions to write nothing that could jeopardise the Slovak-Soviet relations. The Slovakian government was aware of the fact that the Soviet diplomacy would be monitoring the Slovakian press, and they did not want to give any reason that could deteriorate the relations. ${ }^{20}$ The Slovak-Soviet connections were disturbed by the fact that the former Czechoslovak ambassador, Zdeněk Fierlinger ${ }^{21}$ remained in Moscow in 1939 keeping important connections in the Soviet Ministry of Foreign Affairs. However, his position was immediately shaken with the recognition of Slovakia. Molotov ordered his personnel to cut connections with Fierlinger and to stop receiving him officially. The former ambassador did not have to leave the country, however. He was regarded as the representative of a 'symbolic state and country'. ${ }^{22}$

On his return to Moscow, Fraňo Tiso immediately got in touch with the German embassy. In late December 1939, he solicited Bratislava for avoiding expressions in the press and in speeches that could harm the development of their connections with the USSR because

15 Pavol PETRUF, Vzt́ahy medzi Slovenskom a Francúzskom v rokoch 1939-1944, in: Historický časopis, 41, 1993, $5-6,694$.

16 MIČIANIK, 12-13.

17 MARIJNOVÁ, 830.

18 Slovenská politika, 1939, Year 20, No. 64, 24 August, 1.

19 Slovenská politika, 1939, Year 20, No. 66, 19 September, 1.

20 SNA, MZV, PZ, Box No. 198 (The report of the Slovak embassy in Moscow without number.).

21 Zdeněk Fierlinger (1891-1976): Czech Communist politician. Between 1937 and 1939, the ambassador of Czechoslovakia to the USSR. Prime Minister in Czechoslovakia in 1945-1946, then deputy Prime Minister in 19481953.

22 Daniel ŠMIHULA, Vnútorný život na vyslanectve Slovenskej republiky v Moskve v rokoch 1939-1941, in: Historický časopis, 46, 1998, 3, 479-480. 
they would make his job very difficult. ${ }^{23}$ Tiso was among the first to consult the Hungarian ambassador to the Soviet Union, József Kristóffy, ${ }^{24}$ to whom he spoke about Slovak-Hungarian relations. He expressed his liking to Hungary but also articulated his worries about the deterioration of Slovak-Hungarian relations. He attributed this to the Komárom talks, ${ }^{25}$ about which Kristóffy sent this report: "This is apparently a painful point of the Slovak ambassador since he mentioned several times how bitter experience they had been subject to in Komárom, and they had been under the impression that Hungary intended to threaten the independence of Slovakia at any rate. The Vienna Award was another disappointment for them, and it took several months to calm down the distrust, which was fuelled by individual ambitions on both sides, and settle the relations." 26 The Hungarian ambassador endeavoured to convince his Slovakian colleague that there was no Hungarian intention to threaten the sovereignty of Slovakia. Fraňo Tiso replied that he would attempt to establish good connections and even to make a commercial and economic contract with the USSR. This came true several months later. ${ }^{27}$

Slovak political circles, alongside with the general public, received the establishment of diplomatic connections with the USSR with great, probably too great, expectations. According to Jozef Tiso, the agreement between the Germans and the Russians guaranteed that "cooperation between Germanic and Slavonic peoples could be realised in Europe", which should have happened earlier. ${ }^{28} \mathrm{He}$ also came up with the treaty, a landmark in the future of the two nations. Slovak politicians saw the Soviet connection as a possibility to counterbalance the increasing German influence in Slovakia. At the same time, they thought they could count on the support of Moscow against Hungary.

President Tiso thought it important to emphasise the attraction of the Slovak people to the Soviet Union and their hatred of Hungary as early as on 14 February 1940, when he met Pushkin and received his letter of credence. ${ }^{29}$ What is more, Foreign Minister Ferdinand Ďurčanský had complained to Pushkin already on 5 February about the Hungarian occupation of Slovakian territories, but he added that the Slovaks would not give up hopes to regain them in due course. ${ }^{30}$ Duurčanský did not hide his opinion about the Germans: he believed that the Germans had not support Slovakian claims at the First Vienna Award

23 Dagmar ČIERNA-LANTAYOVÁ, Politické úvahy a súvislosti pri nadviazaní diplomatických stykov medzi Slovenskom a Sovietskym zväzom v roku 1939, in: Historické štúdie, vol. 37, Bratislava 1996, 81.

24 Kristóffy, József (1890-1969): diplomat at the Hungarian embassy in Warsaw in 1937-1939. From 30 September 1939 to the end of June 1941, Hungarian ambassador to the USSR.

25 The Komárom talks: The Czech-Slovak-Hungarian negotiations resumed on 9 October 1939 in Komárno. The Czecho-Slovak mission was led by Jozef Tiso, premier of the autonomous Slovak government. The Hungarian delegation was headed by Foreign Minister Kálmán Kánya. The objective of the meeting was to determine the border between the two countries. The Slovaks found the Hungarian demands exaggerated. They offered autonomy to the territories with Hungarian majority in Slovakia, while the Hungarian party demanded them back on the ethnic principle. The negotiations closed without success on 13 October 1938. Both sides trusted German and Italian arbitrators, and therefore asked their decision.

26 Peter PASTOR, A moszkvai magyar követség jelentései 1935-1941, Budapest 1992, 148 (doc. no. 221).

27 The treaty of commerce between Slovakia and the USSR was signed on 6 December 1940.

28 Slovák, 1939, Year 21, No. 227, 3 October, 2-3.

29 MARIJNOVÁ, 833.

30 ČIERNA-LANTAYOVÁ, 1996, 84 
because they had been afraid to elicit the resentment of their ally Italy. ${ }^{31}$ All this shows that the Slovak administration saw the opportunity in Moscow not only to counterbalance the German influence to some extent but also to get an ally in their dispute over territories with Hungary. ${ }^{32}$ Durčanský explained to Pushkin that the Germans 'did not like him' due to his policy, which, as it will be seen, would lead to his fall. ${ }^{33}$ Tiso had the impression that Pushkin was neither an atheist nor a Bolshevik; what is more, he promised Tiso not to spread Socialist propaganda in Slovakia. In his report to Moscow, after the audience, Pushkin emphasised that "the Slovaks unambiguously declared their attraction to the Soviet Union". He also thought that the Germans had created Slovakia as a buffer state between the German Empire and the USSR. ${ }^{34}$

\section{The Establishment of Soviet-Hungarian Diplomatic Relations}

Hungary and the Soviet Union established diplomatic connections in 1934. There had been earlier attempts but they failed as certain Hungarian leaders were afraid of possible Communist propaganda activity on the part of the Soviet embassy.

The connections were untroubled until 2 February 1939 when they were broken for a while. The Soviets were disappointed at Hungary joining the Anti-Comintern Pact. ${ }^{35}$ Foreign Commissar Maxim Maximovich Litvinov told the Hungarian ambassador to the USSR Mihály Jungerth-Arnóthy ${ }^{36}$ that his government closed the embassy in Budapest and that they expect Hungary to do the same. The Soviet government proposed that they should communicate in a third state through their embassies there. ${ }^{37}$ The Soviet diplomacy resented the fact that Hungary subordinated herself to the German pressure too easily and thereby lost her independence. They stressed that the suspension of direct connections did not mean the severance of relations. ${ }^{38}$ The two governments finally agreed to keep contact through their embassies in another capital city. ${ }^{39}$ As Moscow had lost a resource of information with the closure of the embassy in Budapest, the Soviet embassies in the neighbouring states became more important. Diplomatic relations eventually resumed in September 1939. The Hungarian ambassador, József Kristóffy, arrived in Moscow in mid-October, and Nikolay

31 MARIJNOVÁ, 833.

32 Ferdinand ĎURČANSKÝ, Biela kniha, vol. II., Trenčín 1991, 294.

33 ČIERNA-LANTAYOVÁ, 1996, 85.

34 MARIJNOVÁ, 833, 838.

35 The Anti-Comintern Pact was made by Germany and Japan on 25 November 1936. It was, in theory, an anti-Soviet agreement. Italy joined in 1937, while Hungary joined on 24 February 1939.

36 Jungerth-Arnóthy, Mihály (1883-1957): career diplomat; the Hungarian ambassador in Moscow in 1934-1939. Between 1939 and 1944, the head of the embassy in Sofia.

37 Magda ÁDÁM, Magyarország külpolitikája. Diplomáciai iratok Magyarország külpolitikája, vol. III, Budapest 1970, 285 (doc. no. 421).

38 SERES, 2000, 89-90.

39 Attila SERES, Orosz levéltári források a magyar-szovjet diplomáciai kapcsolatok történetéhez (1939), Lymbus 2005, 227-228. 
Sharonov ${ }^{40}$ took his office in Budapest in late November. The German-Soviet approach also played a role in the restoration of the Soviet-Hungarian relations. Interestingly, the opening of the Soviet embassy in Budapest had an impact on the Slovak-Hungarian relationships as well. The Slovakian ambassador in Budapest, Ján Spišiak ${ }^{41}$, welcomed it heartily. He felt that he experienced quite a different tone in the Hungarian Ministry of Foreign Affairs from then. He thought that the Hungarians evaluated Slovakia more highly as a Slavonic state supported by the USSR. Spišiak adviced Sharonov to publish 2-3 articles praising Slovakia in the "Pravda", which, in his view, "would be worth 2-3 divisions". ${ }^{42}$

In the Soviet-Hungarian relations Subcarpathia meant a debatable question. Soviet troops reached the former Polish-Hungarian border on 25-26 September 1939. The appearance of the USSR on the ridges of the Carpathian Mountains created a new source of conflict. The Russians were afraid that if Subcarpathia got into the German sphere of interest, it could become a 'Ukrainian Piedmont', and ultimately lead to the formation of Great Ukraine. ${ }^{43}$ The Germans did have such plans but Hitler abandoned them after his agreement with Stalin in August 1939. Although the Russians apparently protested against the Hungarian advance in Subcarpathia, it was, in fact, to their advantage, for Ukrainian nationalists could not be really effective under Hungarian control. The Hungarian administration, distrustful and anxious regarding the Russians, had to know whether the USSR acknowledges the new borders of 1939. The Soviet leadership officially denied having any claims for Subcarpathia. ${ }^{44}$ The words of Staff Colonel Anton Gerasimov, who led the delegation which returned the Hungarian military banners of 1848/49, support this: "Hungary can never be afraid that the Soviets would claim a patch of land from present-day Rusinsko; primarily for two important reasons: changing the current natural borders would be unnecessary for the tiny land in question, nay they endeavour to create natural borders everywhere. Russia with her 200 million people does not need the Rusins ..."45

Ján Spišiak came up with the issue of Subcarpathia for Nikolay Sharonov on 20 December 1939. Sharonov avoided a lengthy discussion and said that this region had never formed a part of the Russian Empire or the USSR and they did not want to change the situation. ${ }^{46}$ The Soviet Union acknowledged the territorial gains of Hungary in 1938-1939, and the question of Subcarpathia was postponed. On analysing Soviet-Hungarian relations it can be concluded that the influence came from the German-Soviet connections. Hungary was handled as a German ally and the country was regarded as a potential subject to German expansion in 1939-1941. ${ }^{47}$ From October 1939, the Soviet administration attempted at

40 Nikolay Ivanovich Sharonov (1901-198?): Soviet diplomat. Ambassador in Warsaw in 1939, representative of the USSR in Hungary from autumn 1939 to June 1941. After 1941, he left the Foreign Commissary and later he held various party offices in Ukraine.

41 Ján Spišiak (1901-1981): lawyer, diplomat, university professor. From 1939 (23 May) to 1944, the ambassador of Slovakia in Budapest.

42 Attila KOLONTÁRI, A Szovjetunió és az első bécsi döntés, in: Limes, 74, 2007, 2, 31.

43 Attila KOLONTÁRI, Magyar-szovjet diplomáciai, politikai kapcsolatok 1920-1941, Budapest 2009, 296.

44 Ibidem, 300.

45 ZSELICZKY, 61.

46 KOLONTÁRI, 2009, 305.

47 SERES, 2000, 82. 
developing good connections with Hungary; this was manifested in the return of the 1849 banners and other concessions. The Soviet diplomacy tried to keep Hungary away from the war and to loosen her ties with Germany, which remained wishful thinking.

\section{The Attitude of the USSR to the Slovak-Hungarian Relationship in 1940}

Pushkin and other Soviet diplomats felt that links with Hungary were second to the links with Germany only for Bratislava, and they continually sent reports about this to Moscow. From 1939, Slovak-Hungarian relations were determined by three main matters: 1) control over certain territories with the problem of minorities there, 2) gaining the favour of the Germans at the expense of each other and 3) the principle of reciprocity. Slovakia was one of the smallest states in Europe with her 38,000 square kilometres and 2.6 million inhabitants. $85 \%$ of the population was Slovak while the rest was comprised of Hungarians, Germans, Rusins (Ruthenians) and others. At first, the leaders of the country communicated to their citizens that Slovakia could play the role of a neutral state, similar to Switzerland, between Germany, Hungary and Poland. This remained wishful thinking in the contemporary international situation. Slovakia had lost her independence shortly after her birth as the 'Schutzvertrag', a treaty of protection with Germany was signed on 23 March 1939. The German Reich ensured the independence of Slovakia for 25 years, while Slovakia obliged to maintain her foreign policy in accordance with German interests, to organise her military forces in cooperation with the German army, and also agreed to the creation of the Schutzzone. ${ }^{48}$ The head of state was Jozef Tiso and Hlinka's Slovak People's Party practised a single-party rule.

In 1939, the main objective of Slovak foreign policy was the legal acceptance of the state in both regional and wider European contexts. The country's representatives also wanted to familiarise the international public with the circumstances of the birth of Slovakia and her position as a political entity in Central Europe. The Slovak political leadership formed claims for Hungarian territories and wanted to see the revision of the First Vienna Award. At the same time, the Slovak government tried to prevent the country from getting under foreign domination. All this comprised the fundamental tenets of Slovak foreign policy in 1939-1941.

Pushkin had talks with the German ambassador to Slovakia, Hans Bernard on the Hungarian-Slovakian relations in February 1940. Bernard told him that they had formerly liberated the Hungarians ${ }^{49}$ and then the Slovaks, so both states are obliged to Germany. "We know well that the Hungarians want to get Slovakia. At the same time, Slovakia wants to regain the territories ceded to Hungary. " ${ }^{50}$ In Bernard's view, Germany should remain neutral in

48 The Schutzzone was a 30-40-km-wide territory that ran through Slovakia from the Polish to the Austrian border before the creation of the Protectorate of Bohemia and Moravia. Only the Germans were allowed to build fortifications and station troops on this land.

49 By liberation Bertrand meant the extension of the Trianon borders to the advantage of Hungary.

50 ČIERNA-LANTAYOVÁ, 1996, 85-86. 
the debate of her two allies and maintain good relations with both. ${ }^{51}$ It is not difficult to see, behind the diplomatic statement, the manipulation of German foreign policy, as it tried to turn her two allies against each other and benefit from the situation. After their talks, Pushkin found that the German government openly mocked the Slovaks as they felt like lords in Slovakia and they thought they could do everything.

In early 1940, Durčanský had the illusion that the Slovak state could gain time for an independent action with her foreign and military policy. They wanted to reduce the German influence. ${ }^{52}$ Ďurčanský did not hide his hopes that the USSR could help to regain the territories ceded to Hungary in the First Vienna Award, and he started to speak about it openly. ${ }^{53}$ He built his plans on the ideology of Pan-Slav solidarity. Later Durčanský was trying to use the potential support of Soviet diplomacy as a secret weapon against Hungary.

On arriving in Bratislava, Pushkin immediately realised that the most important question in Slovak foreign policy was their relations with Germany and Hungary. Therefore he held talks with the Hungarian ambassador in March 1940. The Hungarian ambassador explained to him that his job was made difficult in Slovakia: he was disliked, neglected and sometimes discriminated against by the Slovak politicians. It was not easy to normalise and improve the connections between the two countries under such circumstances. He also told Pushkin that the Slovaks were very concerned about the situation of the Slovak minority in Hungary, while following a nationalistic policy with the Hungarian minority in Slovakia, which he found absurd. He also resented having to correspond with the Slovakian Ministry of Foreign Affairs in French even though everyone spoke Hungarian well there. ${ }^{54}$ Pushkin regularly sent his supervisors the copies of the anti-Hungarian articles of the Slovakian press alongside with his comments.

On 4 April 1940, an article with an especially harsh tone against Hungary was published in the journal 'Slovák'. The author clearly hinted the restoration of the borders of Slovakia but only "in a peaceful way". This raised the attention of Soviet diplomacy, and the first secretary of the Soviet embassy in Bratislava, Ivan Alexandrovich Zaitsev, talked with the secretary of Hlinka's Party, Jozef Kirschbaum, over the issue. The latter stressed the importance of the re-annexation of the territories, and said that it was the primary objective of Slovakian foreign policy. He explained that the majority of the Slovaks did not want to participate in the European war for this, but he did not exclude the possibility of a war with

\section{1 lbidem.}

52 Dagmar ČIERNA-LANTAYOVÁ, Problém vztahu s Mad'arskom v aktivitách politikov a diplomatov Slovenského Štátu 1939-45, in: Z dějín Visegrádského prostoru. Richardu Pražákovi k pětasedmdesátinám, Vladimír GONEČ Radomír VLČEK (eds.), Brno 2006, 234-235.

53 Ďurčanský's ideas regarding the Soviets were not unfounded. The Soviet government openly condemned the Munich Pact and the First Vienna Award several times. The USSR did not object to the Hungarian annexation of southern Slovakia but to the circumstances of arbitration, which facilitated the further advance of Germany. "The Soviet political leaders held the re-annexation of Hungarian-populated areas to be the natural consequence of the Munich Agreement. ... and they did not even suggest ... that they would regard it an unfair or violent act." Jungerth criticised the attitude of the Soviet press saying that it served propaganda, which presented Czechoslovakia as a sacrificial lamb. Jungerth drew the conclusion that the Soviet administration might still have territorial aspirations in the future; otherwise they would not have allowed such a sympathetic tone in connection with Czechoslovakia. The Soviet press campaign against Hungary came to an end as late as December 1938 . See PASTOR, 117 (doc. no. 166-167).

54 Dagmar ČIERNA-LANTAYOVÁ, Pohlady na východ, Bratislava 2002, 110. 
Hungary in the near future..$^{55}$

Pushkin felt, and reported to his government in April 1940, that the Germans wanted to use Slovakia to put pressure on Hungary. ${ }^{56} \mathrm{He}$ also followed, with great attention, the Hungarian reactions to the Slovakian attacks. He commented in detail on the speeches of Géza Szüllö57 and Foreign Minister István Csáky in the Hungarian parliament in early April 1940 as well as on the aggressive response of Durčanský on 1 May 1940.

The speech of Szüllö was elicited by events in Slovakia, which also called the attention of Soviet diplomats. There were anti-Hungarian demonstrations in Nagymihály on 21 April 1940. The Minister of Economy in Slovakia, Gejza Medrický58 and the chief secretary of the Slovakian People's Party, Jozef Kirschbaum gave speeches. The latter spoke about the Hungarians in the following words: "There are enough trees in Slovakia to hang the Hungarians on, there is enough lead to make bullets for them and there is enough room in jail to place the Hungarians. The Hungarians are a Jewish-Gipsy race, brought up on horse milk, and what culture they have they received from the Slovaks." 59 The Nagymihály demonstration was not an isolated event: the organisers of the campaigns made sure that other towns in Slovakia would be scenes of similar anti-Hungarian rallies.

On 22 April 1940, anti-Hungarian demonstrations took place in Bratislava. Leaflets were spread in the streets with the demand of the destruction of Slovakian Hungarians. On 24 April, Hungarian sign boards were knocked down with axes and Hungarians were insulted in the streets. Windows of Hungarians' houses were broken. Hungarians and Jews were beaten in the streets and were driven out of cafés and restaurants. The demonstrators also tried to break into the office of the Hungarian Party but they failed and only broke the windows. The violence continued on the following day. Stallkeepers on the marketplace were warned that speaking in Hungarian was forbidden from then on. According to the report on the events the Nitra police did not even attempt to stop the demonstrators. ${ }^{60}$ Another demonstration took place in Kežmarok on 27 April, when, among other things, anti-Hungarian drawings were spread. 1 May saw similar attacks in Levoča, Prešov and Nitra; many demonstrators were members of the Hlinka Guard. The marching crowd stuck posters which read: "From Vác to Miskolc and Poprad, everything is ours! Asia is yours, this land is ours!" "Take guns and helmets against the liars Hungarians!" "Slovakia to the Slovaks, Asia to the Hungarians! (...) We want everything back right now!"61

\section{5 lbidem, 117.}

56 MARIJNOVÁ, 836.

57 Szüllő, Géza (1872-1957): Czechoslovakian Hungarian politician and lawyer. In 1920, he was one of the founding members of the Hungarian National Christian Socialist Party; in 1925-1932, president of the party. MP in Prague. After the First Vienna Award, MP in the Hungarian Parliament (1938-1944). After 1945, he retired from politics and lived in Hungary.

58 Gejza Medrický (1901-1989), Slovak politician, MP and journalist; Minister of Economy in the Republic of Slovakia.

59 Magyar Nemzeti Levéltár Országos Levéltára (National Archives of the Hungarian State Archives; hereinafter referred to only as MNL-OL), fund Miniszterelnökség (Prime Minister's Office; hereinafter referred to only as ME), K 28, Bound 25, Item 65, No. 17528/1940.

$60 \mathrm{MNL}-\mathrm{OL}, \mathrm{ME}, \mathrm{K} 28$, Bound 25, Item 65, No. P 17339/1940.

61 MNL-OL, Külügyminisztérium (Foreign Ministry; hereinafter referred to only as KÜM), K 63, Bound 460, No. 15178/1940 (18 May 1940). 
In Prešov, Alexander Mach ${ }^{62}$ gave an anti-Hungarian speech: "The fate of Central Europe may be decided soon. ${ }^{63}$ We have nothing to fear. Also the foreign press acknowledges our capability of existence. During our thousand-year oppression the world knew us as tinkers thanks to our oppressors. It is not so today. Hungary envies us, they would like to be in our place. The Hungarians should deal with themselves and their own problems." 64 Fanning the anti-Hungarian atmosphere further worsened the situation in Slovakia. The Hungarian ambassador to Berlin had to protest at German state secretary Ernst Woermann about the attacks of the Slovak and German press against the Hungarians. Sztójay was of the opinion that certain members of the Slovakian government supported the activity. The Hungarian government was interested in keeping good connections with Slovakia; that is why the Hungarian press had not responded to the Slovak attacks and remained silent. Woermann told Sztójay that he had been visited by the Slovak ambassador, who said exactly the opposite. He drew Sztójay's attention to the fact that Slovakia was in her adolescent years, and they endeavoured to have an educational effect on her. The Hungarian ambassador responded in the following way: "If they are the parents, it is all the more their duty to discipline her when she puts out her tongue at her thousand-year-old grandparents." 65 Woermann promised to intervene at the Slovak government for the cessation of the anti-Hungarian actions but he added that he had to do it very carefully because Slovakia was very sensitive to her sovereignty. In conclusion to their talks Sztójay told the Hungarian government not to expect Germany to create a pro-Hungarian attitude in Slovakia.

Germany attacked Denmark and Norway on 7 April 1940, which raised new hopes in Slovakia. They expected to get the opportunity to enlarge their territory. The victory of the Germans was also the glory of the Slovaks, they said all over the country. ${ }^{66}$ News arrived from Vienna that twenty German divisions were ready to march against Romania through Hungary. Mach and the Hlinka Guard began anti-Hungarian agitation to this; they called all to arms against the Hungarians, "whose last hour had come", they thought. They started to spread the information that the Slovaks, alongside the Germans, would also march to Hungary; they would occupy all the land that should duly belong to them as far as the Danube flows, and liberate the Hungarian peasants from the rule of the counts and the Jewish barons. ${ }^{67}$ These threats elicited resentment in Hungary.

As a response, Géza Szüllo gave a sharp speech about the Slovak behaviour in the Upper House of the Hungarian parliament on 30 April 1940. He emphasised that he did not want to create tension between the two states but he could remain silent no more. Hungary had maintained friendly connections with Slovakia until then but the Slovak leadership had taken aggressive steps against her. Even though Slovakia was a Schutzstaat, she did not

62 Alexander Mach (1902-1980): Slovak politician. Editor of the 'Slovák', the periodical of the Slovakian People's Party, from 1920 to 1939. He belonged to the radical wing of the party. Accused in the Tuka trial but quitted. Minister of the Interior and chief commander of the Hlinka Guard in the Slovak Republic. In 1947, he was sentenced to 30 years in prison. Released during amnesty in 1968.

63 He meant the war of Germany against Britain and France.

64 MNL-OL, ME, K 28, Bound 25, Item 65, No. K 17666/1940.

65 MNL-OL, KÜM, K 63, Bound 460, No. 97/pol. 1940 (8 April 1940).

66 MNL-OL, KÜM, K 63, Bound 459, No. 133/pol. 1940 (20 May 1940).

$67 \mathrm{lbidem}$. 
behave accordingly. "There are embers under ashes in Slovakia, and those who want to burn our dreams want to make a fire of those embers. [...] We Hungarians have always noticed the pin-pricks and stings that the government, the press or the Slovak nation thought appropriate to use against us both in Slovakia and here. However, they had no influence on the sovereignty of the state and we did not take them into consideration seriously, gave no response to them because we must not forget our manners. "68 Szüllo also said that there had been anti-Hungarian incidents in several towns of Slovakia from 25 April 1940 onwards. He highlighted the one in Nitra where, as he said, the local leader of the Hlinka Guard said as follows: "[...] Those who speak Hungarian in Nitra or Slovakia, must have their tongues torn out, those who speak Hungarian in the republic must be silenced."69 Szüllo also reproached the fact that the Slovak demonstrators had broken the windows of the Hungarian embassy in Bratislava and the local police did not prevent it. He found it unacceptable that anti-Hungarian leaflets which call for military action to conquer territories in Hungary as far as Szolnok and the Tisza River were spread in Slovakia. In Szüllo's opinion the Slovaks had begun a dangerous game; it was their purpose to spoil the Hungarian-German relationship while another group was seeking agreement with the circle of Beneš. He also made critical reference to Mach: if the Germans made manoeuvres in Slovakia, Mach would interpret it as if they had obtained the consent of Germany to retake the territories lost in the First Vienna Award. Szüllo asked the Hungarian leaders to take steps against the Slovak political attacks and force Slovakia to develop better relationship with Hungary using economic contracts: "I am asking the government to make it clear that even though Hungary is a small state, she can be strong being aware of her rights against those who violate them or fail to understand her noble gesture."70

István Csáky responded to Szüllő's words by expressing his regret, on behalf of the whole Hungarian nation, that the friendly right hand reached out to the Slovaks had met with no appropriate reception, and some groups were trying to spoil the Hungarian approach with malevolent slanders. The Hungarian government was endeavouring, with the utmost self-control, to build acceptable relationship with Slovakia. It had overlooked a lot for the sake of peace and tranquillity and it was willing to continue with such patience because it was considering not only the activity of the present-day leaders but also the future of the two friendly nations. Csáky said that he knew the atrocities mentioned by Szüllö and he had already consulted them with the Slovakian authorities but the policy of Hungary had to be cautious and self-controlled in the current international setting. Still, it was the last straw when the Hungarian government had to act. "Our patience will run out if the Slovakian Hungarians' right to life and property as well as the Hungarian subjects' right to their property in Slovakia is violated in any way. ${ }^{71}$, Csáky said threateningly. He emphasised that Hungary is not weak and is ready to protect her interests, but he finally pointed out that his government intended to continue the policy of patience and peace. Csáky's words can be interpreted as a warning to the Slovak leaders to stop the persecution of the Hungarian

68 The Records of the Upper House of the Hungarian Parliament. Vol. I-II,Budapest 1940-1941, 283-284 (session 22, 30 April 1940).

69 Ibidem, 284.

70 lbidem.

71 lbidem. 
minority. Szüllö's speech made the politicians think in Slovakia, and it also raised doubts to the great hopes of the public for revision. Suspicion was aroused that the Hungarian MP's words could hint at a Hungarian-German agreement at the expense of Slovakia, which could lead to further territorial losses.

However, Spišiak gave no credit to Csáky's threat. He thought that Csáky only took the opportunity to gain popularity, and that "no great importance should be attached to it" ${ }^{72}$ Csáky explained to Spišiak that he had to give that speech against his will on Szüllö's pressure, but he wanted to develop the relationship with Slovakia anyway.

In the Slovak parliament, MP Konštantín Čulen ${ }^{73}$ remarked on Szüllő's words. He referred to the fact that "the Hungarians had adopted their culture from the Slavs and had the Slovaks not been so soft, Petőfi would not have written under such a name." The Hungarians do not deserve grace for the establishment of economic connections because they needed the Slovak timber, which they had purchased for their surplus. The Slovaks did not want more than what they could claim legally; they wanted the Hungarians and Slovaks to belong to Hungary and Slovakia respectively. "The Slovaks never want to live under the crown of St. Stephen; if somebody forced them to do so, they would rather burn their villages, towns, churches, schools and houses, they would let themselves be killed to the last man rather than return to the state link that had been worse than slavery. " ${ }^{74}$ Culen pointed out that they had no problem with the Hungarian people; they would take steps only against the aristocrats and the plutocrats: "They will liberate the Slovaks as well as the oppressed Hungarian peasantry on the territories ceded to Hungary and after this mission, the Slovaks will join us." 75 János Esterházy was present at Čulen's speech but he did not remark upon it immediately. However, he denied later, supporting his claims with facts, that the situation of Hungarians in Slovakia was excellent and they would have so many rights as Culen claimed. The Hungarian ambassador in Bratislava protested against Čulen's speech at his German colleague.

The Hungarian ambassador, György Szabó, had the impression that the German administration made no remarks on Čulen's speech because they wanted to spare Slovaks' dignity. "Since they want to set an example with Slovakia as a sovereign state under German protection towards the 'Südost', they want to avoid the implication, by regulating her in public, that doubts can be raised regarding her independence." ${ }^{76}$ By leaving Slovak ideas for revision without comment, the Germans let domestic tensions calm down, in order to prevent public opinion from turning against Germany. They thought it possible that the Slovaks could turn to Edvard Beneš or to Moscow for patronage. The Hungarian ambassador did not think that the Slovaks were planning to march into Hungary with German

72 Tibor FRANK (ed.), Roosevelt követe Budapesten. John F. Montgomery bizalmas politikai beszélgetései, 1934 1941, Budapest 2002, 277.

73 Konštantín Čulen (1904-1964): Slovakian writer, journalist, MP and politician. Until March 1940, cultural attaché of Slovakia in Washington. In 1945, he emigrated to Austria, then to Canada, from where he attacked Czechoslovakia with his writings. He was one of the main supporters of the rehabilitation of Jozef Tiso. In 1948, he was sentenced in his absence to 30 years in prison by the Czechoslovakian law court.

74 MNL-OL, ME, K 28, Bound 44, No. 124/pol. 1940 (6 May 1940).

75 Ibidem; Slovák, 1940, Year 22, No. 107, 8 May, 3.

76 MNL-OL, KÜM, K 63, Bound 459, No. 120/pol. report and its enclosed document (7 May 1940). 
troops. In fact, as some sources show, they were afraid that the Hungarian-German relationships would develop to the disadvantage of Slovakia. Szabó drew the attention of his government to the fact that no punitive action was possible against Slovakia without German approval. "Such an action without a preliminary agreement could offer a pretext and opportunity to the empire, on grounds of guaranteeing the protection of Slovakia, to settle the constantly topical 'transit' question ${ }^{77}$ through Hungary with arms. ${ }^{78}$

Ferdinand Durčanský made an onslaught on Hungary in Bratislava on 1 May 1940. He scolded the "counts" and claimed that they were the primary obstacle in the agreement of the two countries. "[...] it is not the fault of the Slovak government that they are riding such a high horse in the South, that they are speaking to the Slovaks from such a height that the horseman cannot see the ground. And if the horseman does not look down to the hooves of his horse, he cannot see when the horse stumbles and he could fall off. It is not the fault of the Slovak government either that a Slovak cannot understand how they can speak about brotherhood in the south when he has the experience that the face that turns to us strongly resembles the face of Cain. Nevertheless, we assure everyone that we will not play the role of Abel." 79 He added that the Slovaks wanted peace. They wanted Slovakia to be a state where all Slovaks, $45 \%$ of which lived abroad, would find a cosy home.

The Slovak-Hungarian diplomatic and political debate drew the attention of Moscow; they gave instructions to their ambassador to discover the background of the case. Pushkin, when meeting the Slovakian foreign minister, asked him to explain the reason of the harsh tone of the speech. Durčanský, who was on good terms with the ambassador, said that he had merely mirrored Csáky, who laughed at Slovakia in his speech at the Hungarian parliament. He wanted to teach the Hungarian foreign minister a lesson so that he would not make similar remarks any more. ${ }^{80}$

The Soviet ambassador in Budapest, Nikolay Sharonov, talked with Csáky about the Soviet-Hungarian relations on 11 July 1940. Csáky explained to him that the Slovaks tried to use Germany against Hungary and were constantly intriguing against Hungary anyway. He also mentioned that the Slovak ambassador in Moscow, Fraňo Tiso, had behaved like a "conspirator" in the presence of Hungarian diplomats. Fraňo Tiso never failed to mention to the Hungarians that the cooperation between the Soviets and the Slovaks was excellent and that great things were being prepared between them, about which he must not speak. He gave hints about a possible Slovak-Soviet action against Hungary. When asked about these "great things" by Csáky, Sharonov could give no substantial answer.

Durčanský thought that Slovakia, enjoying the support of the USSR, could take brave steps against Hungary. He started to spread the information, through Fraňo Tiso, that the USSR would regard a possible Hungarian attack against Slovakia a casus belli. ${ }^{81}$ The Soviets made no declaration in this question. Durčanský wanted to emphasise the intimacy of Soviet-Slovak relations and to frighten Hungary away from any radical steps. Pushkin was also

77 That is, the passage of German troops through Hungary.

78 MNL-OL, KÜM, K 63, Bound 459, No. 120/pol. report and its enclosed document (7 May 1940).

79 Ibidem.

80 ČIERNA-LANTAYOVÁ, 2002, 118.

81 PASTOR, 170 (doc. no. 243). 
contacted those days by the first secretary of the Hungarian embassy in Bratislava, Zoltán Sztankay, who complained that the anti-Hungarian campaign on the part of Slovak politicians was growing intolerable. He explained to the Soviet ambassador that Csáky's speech had not been aggressive nor had it had any political intention. Mach and Durčanský, however, openly claimed territories in their speeches. He added that the Hungarian politicians did not take such outbursts too seriously as it was known in Budapest that the Germans were interested in keeping peace in Central Europe. ${ }^{22}$ Pushkin was wondering, in his summarising analytic report, whether Germany was to use Slovakia to attack Hungary in due course or to use her as an item in some barter with Hungary in the future. He thought that Durčanský wanted to weaken German influence and secure the sovereignty of Slovakia. ${ }^{83}$ Interestingly, an Italian note provides some details about the Hungarian-Slovak relations and the Soviet threat. The Italian ambassador in Budapest sent a report on his talks with Csáky about the Slovak-Hungarian relations to Foreign Minister Galeazzo Ciano. He wrote that Csáky found the German intentions concerning Slovakia still undecided. In Csáky's view, Slovakia was the last "open door" in Central Europe for the Slavonic threat, that is, Soviet expansion: the Soviets could advance towards Czech and Polish territories through Slovakia. Csáky also knew that some Slovak politicians had close connections with Moscow and Beneš. The Hungarian foreign minister thought that the Slovak ambassadors in Rome and Budapest were Benešs agents and dedicated Pan-Slavs, which could pose a threat on Hungary as well as the great powers. Csáky drew the following conclusion from that: it would be the interest of Europe, primarily of Italy and Germany, to give Slovakia to Hungary "[...] in order to create an anti-Slavonic wall in the foreground and to destroy the confrontation line between the Germanic and Slavonic races. It would be also the fundamental interest of Hungary, which is worth any effort". ${ }^{84}$

All this clearly shows that certain leaders of Hungarian foreign policy did not give up the possibility of getting Slovakia even in early 1940. Csáky emphasised the Soviet threat in connection with Slovakia.

In mid-June 1940, a rumour spread in Bratislava that the USSR had sent an ultimatum to Hungary: the Hungarian government must withdraw its troops from Subcarpathia within 24 hours. Later, this information proved to be false. Although they listened to it with interest, Soviet diplomats in Bratislava did not comment on it in the news. Slovakia would have supported the Soviet occupation of the territory formerly belonging to the Czecho-Slovak state and annexed by Hungary in November 1938 and March 1939. Ďurčanský discussed this issue with Pushkin on 16 June 1940. He openly declared that he would welcome a Slovak-Soviet border and tried to convince Pushkin that the USSR could take Subcarpathia and Bessarabia while Germany was busy with Romania. ${ }^{85}$ The Soviet ambassador replied that they did not consider Subcarpathia such an important territory that would deserve much discussion. Durčanský agreed with this but pointed out the military-strategic significance of Subcarpathia, which was clear for the Hungarians, the Germans and the Italians, and

\section{2 lbidem.}

83 ČIERNA-LANTAYOVÁ, 2002, 118-119.

84 György RÉTI, A Palazzo Chigi és Magyarország. Olasz diplomáciai dokumentumok Magyarországról a Darányi-kormány megalakulásától a szovjetunió elleni hadüzenetig, 1936-1941, Budapest 2007, 328.

85 MARIJNOVÁ, 835. 
therefore they did not want to leave it to the USSR. Some Slovak politicians were hoping that if the Soviet Union entered this territory, it could replace Italy as an arbiter at future peace negotiations and territorial reconstructions. This could be an unfavourable development for Hungary. The Soviet-Slovak common border would apparently open possibilities for the otherwise rather isolated Slovak foreign policy, but the Soviet diplomats would not get involved in talks about Subcarpathia and Slovak-Hungarian relations. It was clear, now, that the USSR would not assist the realisation of Slovak plans for revision. This meant that the Slovak ambitions depended on the help of Berlin.

Both Ján Spišiak and Csáky wanted to denigrate each other before ambassador Sharonov. The main "accusations" were the oppression and forceful assimilation of the Hungarian minorities that remained in Slovakia and the Slovak minorities now living on Hungarian soil respectively. They also mutually resented "intriguing" at the Germans. To the disappointment of the Slovaks, Moscow hesitated to take any steps that could lead to conflict with Germany. Berlin made it clear for the Soviets several times that they regarded Slovakia as their exclusive sphere of interest, where they would not tolerate any rival. Pushkin put it in his remark that "the Slovaks expect more from us than we can offer to them". ${ }^{86}$ He meant political support, and he felt he was in a privileged position in Bratislava. Although he called Slovakia an important watching station, he could see no opportunity for the further development of relations "as long as the Germans rule there". As the USSR was at war with Finland in 1940, she would not risk a war with Germany about Slovakia, and therefore did not have too much ambition in Slovakia. At first, the Soviet administration hoped that Slovakia would make a treaty of friendship and economic cooperation with them, as she had done with the Germans, and that would give them the opportunity to increase their influence in the country. ${ }^{87}$ When the Germans stood up "in defence" of their satellite, the Soviets gave up their ideas. They realised that Pushkin was right when he wrote in December 1940 that they could expect nothing from Bratislava as the Slovaks follow an entirely pro-German policy. ${ }^{88}$ The location of Slovakia was vital in German East European plans; Berlin could not afford to leave it to another power.

\section{The Consequences of the Salzburg Talks on the Slovak-Hungari- an-Soviet Relations}

The Hungarian political leadership also resented the fact that Foreign Minister Ferdinand Durčanský and the Slovak leaders were making friends with the Soviets and they alertly followed every step of theirs. When the Slovak Minister of Education Jozef Sivák travelled to Moscow for negotiations, and met Soviet Foreign Minister Vyacheslav Molotov, in early

\footnotetext{
86 Ibidem, 834.
}

87 Ján RYCHLík, Genéza vzt́ahu mocností k možnosti samostatného Slovenska či obnovy Československa, in: Slovensko na konci druhej svetovej vojny. Stav, východiská a perspektívy. Zborník materiálov zo sympózia z ČastejPapierničky 23. 11. - 25. 11. 1993, Valerián BYSTRICKÝ - Štefan FANO (eds.), Bratislava 1994, 122.

88 Ibidem. 
May 1940, the Hungarians thought the time had come to act. ${ }^{89}$ Premier Pál Teleki wrote to Hitler drawing his attention to the Pan-Slavonic threat and the advance of Bolshevism. In Teleki's views, the Soviet Bolshevism had changed its former tactics and was now trying to influence the Slavonic nations. They wanted to expand their ideology as far as Bratislava. ${ }^{90}$ German political analysts confirmed the distrust of the German administration regarding Slovak foreign policy and the person of Durčanský. ${ }^{91}$ In April 1940, they reported the advance of the USSR and emphasised the Pan-Slavonic attitude of Durčanský to their supervisors. ${ }^{92}$ Therefore Germany soon decided to regulate her ally. Jozef Tiso, Vojtech Tuka and Alexander Mach had talks with Hitler in Salzburg on 27-28 July 1940.93 Although not formally invited, Durčanský appeared in Salzburg only to return after feeling embarrassed about not having been invited to the actual scenes of the negotiations. The Slovak delegation gave Hitler a memorandum with maps in which they outlined the situation of the Slovak minority in Hungary, and the symptoms of assimilation were accompanied by data on the German minority in Hungary. The memorandum highlighted six closed regions: 1) Verebély-Surány, 2) Losonc, 3) Jolsva, 4) Kassa, 5) the territory north of Sátoraljaújhely, and 6) the whole Szobránc district. It was emphasised in the epilogue that peace in Central Europe could only be guaranteed by just borders that follow the ethnic principles. Slovakia wanted to reach this by gathering the Slovak population that currently lived outside the country. ${ }^{94}$ In ethnically mixed areas, they proposed an exchange of population between Hungary and Slovakia. They pointed out that the number of Slovaks in Hungary was too high for the Republic of Slovakia to neglect them, and therefore revision was inevitable. ${ }^{95}$ During the Salzburg talks, the Fuhrer accused Tiso and his country of approaching PanSlavism and the USSR. Tiso replied with these words: "We belong to the Slavs, but we

89 Vyacheslav Molotov, Jozef Sivák and ambassador Fraňo Tiso met on 10 May 1940. Besides the Soviet-Slovak relations, the issue of the Hungarians was also touched upon. SNA, MZV, PZ, Box No. 198. Diplomatic annoucement 11 May 1940.

90 Documents on German Foreign Policy 1918-45. (Henceforward: DGFP) Series D. Volume IX. The War Years September 1, 1940 - January 31, 1941. Eds.: Sweet, Paul R. et al. London, Her Majesty's Stationery Office, 1961. No. 284. sz. 392-395. This letter also played a role in the fall of foreign minister Durčaňský later.

91 DGFP, 407. sz. 539-540.

92 lbidem, 540.

93 On the Salzburg talks, see: Lubomír LIPTÁK, Príprava a priebeh salzburských rokovaní roku 1940 medzi predstavitel'mi Nemecka a Slovenského štátu, in: Historický časopis, 13, 1965, 3, 329-365; Miroslav PEKNÍK (ed.), Dokumenty slovenskej národnej identity a štátnosti, vol. II, Bratislava 1998, 263-265; Jörg K. HOENTSCH, Základné črty ríšskonemeckej politiky voči Slovensku pred Salzburgom (marec 1939 - júl 1940), in: Historik v čase a priestore. Laudatio Ĺubomírovi Liptákovi, Ivan KAMENEC - Elena MANNOVÁ - Eva KOWALSKÁ (eds.), Bratislava 2000, 242-247.

94 If the Hungarians thought in terms of the St. Stephen state theory, the Slovak ideology was based on the theory of Great Slovakia and the Great Moravia. In the context of the latter, Great Slovakia would include the territories lost in the First Vienna Award as well as the territories in Moravia with Slovak population. Jews, Hungarians, Czechs and Gypsies would be expelled from Great Slovakia, while Slovaks would be brought home from the USA. This would result in a homogeneous society with sufficient population to resist both Czech and Hungarian ambitions. The response to the ideology of Hungarian thousand-year past and 'cultural superiority' was also created: according to the Slovak version, the empire of Pribina saw the development of advanced culture while the Hungarians softened the meat under their saddles on the Asian prairies.

95 MNL-OL, KÜM, K 63, Bound 459, No. 163/1940. pol. (29 July 1940). 
are primarily Christians, and so we cannot go together with the Bolshevik movement". 96 He definitely denied having Pan-Slavonic objectives. "Tiso assigned the spread of leaflets that called for the support of this policy to the Jews, the Hungarians and the Czechs, who wanted to accuse Slovakia before Germany".97

Hitler explained to Tiso in Salzburg that he only wanted Slovakia to "openly and firmly declare loyalty for the German case in terms of domestic policy". He did not intend to apply force. If Slovakia did not want it, Germany would defend only the Carpathian border and withdraw elsewhere in the same way as she had done in the Baltic States, who surely regret not having signed even a non-aggression treaty with Germany and face the direct consequences of their behaviour. ${ }^{98}$

Hitler also made it clear that his only aim was to see Slovakia and her people healthy and strong, and to grant them a sovereign state. ${ }^{99}$ Tiso promised Hitler that he would not be disappointed with the Slovaks, and asked him for more frequent opportunities for negotiations. Tiso also emphasised that the people of Slovakia count on the protection of Germany and assured the Fuhrer that the Slovaks were ready to take part in the implementation of his plans.

Hitler answered that "the formation of a sovereign Slovak state does not fit in the conception of all European states". Referring to Hungary, he added that "elsewhere they speak about thousand-year-old borders, foreign national ambitions and social problems." 100 Tiso replied with the issue of the Slovak minority in Hungary when Ribbentrop interrupted: it was not a topical question at the moment but the time could come in due course. The Slovak leaders were inspired by his remark. Hitler confirmed during the talks that Slovakia was a free and sovereign state. He neither promised nor rejected the question of territorial revision; he left it for a post-war settlement. Hitler asked the Slovakian administration for the replacement of Ďurčanský and for a more radical and more dedicated pro-German attitude. Tiso had to accept the German demands in Salzburg and sacrifice Durčanský. ${ }^{101}$ Still, the Slovak leaders regarded the talks as a small victory, which they wanted to exploit with propaganda. Tuka cited Ribbentrop in his speech on 30 July 1940: "the Slovaks are close to the heart of the Fuhrer". ${ }^{102}$ Durčanský had to leave his office after Salzburg; he was succeeded by Tuka, while Mach became minister of the interior. The former was so astonished by his dismissal that he merely wrote a letter to Tiso, in which he reminded the premier of his merits at the time of the birth of the Slovak state. He also emphasised his loyalty to Germany and expressed his resentment at his replacement.

96 SNA, Národný Súd, (National Court) Item on microfilm 41, II-A, 925, Jozef Tiso.

97 Andreas HILLGRUBER (ed.), Staatsmänner und Diplomaten bei Hitler. Vertrauliche Aufzeichnungen über Unterredungen mit Vertretern des Auslandes 1939-1944, Frankfurt 1970, 191.

98 The Baltic states were occupied by the USSR. See: György RÁNKI, Hitler hatvannyolc tárgyalása 1939-1944. Hitler Adolf tárgyalásai kelet-európai államférfiakkal, Budapest 1983, 148.

99 HOENTSCH, 245.

100 RÁNKI, 189-190.

$101 \mathrm{It}$ is interesting that Pushkin, in his reports, did not regard this event as a milestone but the fact that Slovakia lost her own foreign political independence with the surrender of France in 1940. Dagmar ČIERNA-LANTAYOVÁ, Poznámky sovietskeho zástupcu v Bratislave k prejavom napätia medzi Slovenskom a Mad'arskom február 1940 apríl 1941, in: Historické štúdie, 43, 2004, 244.

102 MNL-OL, KÜM, K 63, Bound 460, No. 171/pol. 1940 (7 August 1940). 
Slovakian historical literature counts the Salzburg talks among the most significant events in the development of the political system of the Slovak Republic during the war. After the negotiations, National Socialist ideology and its government practices were quickly introduced in Slovakia. ${ }^{103}$ The Slovakian state stepped into the second stage of her history. Mach and Tuka proclaimed the arrival of the National Socialist era, and the country developed a strong Fascist attitude. The removal of Durčanský meant the end of Soviet influence; Pushkin said that the German ambassador "has become, in effect, dictator of Slovakia". ${ }^{104}$ Soviet diplomats in Bratislava were limited in their free movement and their activity was more closely observed. Pushkin remarked, after the Salzburg talks, that the Slovak authorities showed greater loyalty to the Germans than before. He said to the German ambassador in Bratislava, Ludin, at a reception before a great audience: "The Slovaks are as loyal to Hitler as the Germans" and "they are obedient children of their father Hitler." 105 In the wake of the Salzburg talks, also the Slovak press adopted a more moderate tone in connection with the Hungarians for a time. This is evidenced by the information received by Pushkin. In June 1940, the Slovak foreign policy feared that the nightmare might come true: the Germans giving Slovakia to Hungary. The visit of Pál Teleki and Csáky to Germany on 10 July 1940 strengthened the worry. Pushkin wrote about it in his report: he noticed the former intensity of the anti-Hungarian campaign of the Slovak press, while there was deep silence on the visit of the Hungarian politicians. What is more, the Slovak press did not reply to the articles in the Pester Lloyd, which attacked the policy of the Slovak administration. In Pushkin's view, Berlin had clearly forbidden the propagation of Slovak revisionist ideas. $^{106}$

However, the Slovak press started its attacks again in September 1940, which was accompanied by demonstrations all over the country. Pushkin commented on them as follows: "It is hard to assume that the Slovaks acted of their own free will." 107 He thought that the Germans were responsible for the incidents as they were supporting the Slovaks with their silence. In his opinion, the fact that the Slovak-Hungarian border question had been put on the agenda could always be explained by the conflicts in the German-Hungarian relations. Revisionist hopes in Slovakia renewed whenever the Hungarian government failed to meet the requirements soon enough or when they did not support some of the German demands. The German diplomacy always succeeded in harnessing the Slovak ambitions at the expense of the Hungarians, and they could set limitations to the revisionist dreams in Bratislava if they wanted. ${ }^{108}$

The rivalry between the two states for the favour of Hitler since 1939 led to the wish to gain distinction on the battlefield. Therefore, both states joined the war against the USSR, alongside the other satellite states. Tiso said that Slovakia needed to fight against the Soviet Union because this could provide grounds for reclaiming Hungarian territories.

103 Ivan KAMENEC, Trauma, Solymár 1995, 89.

104 MARIJNOVÁ, 842.

105 Ibidem, 844.

106 ČIERNA-LANTAYOVÁ, 2002, 110.

107 ČIERNA-LANTAYOVÁ, 2004, 246.

108 Ibidem. 
From 1939-1941, the USSR refused to be an arbitrator in the Slovak-Hungarian dispute. After Slovakia entered the war against the USSR, the Soviet attitude changed significantly, for which there had been signs earlier. The Soviet government decided to restore Czechoslovakia after Slovakia entered the war. As early as on 4 July 1941, the Soviet ambassador to London, Ivan Maisky, asked Beneš for an appointment, which took place on 8 July 1941. ${ }^{109}$ Maisky pointed out that the Soviet Union intended to renew Czechoslovakia. ${ }^{110}$ Shortly afterwards, the USSR acknowledged the emigrant Czechoslovak government and promised the restoration of the pre-Munich borders. ${ }^{111}$ With their joining the war against the USSR, the Slovaks lost all hopes for the slightest Soviet support for their independence in the future.

Slovak-Hungarian relations further deteriorated during the war. In November 1941, Hungary almost broke diplomatic connections with Slovakia. During 1939-1941, the Soviet diplomacy observed the development of their relations from the aspect of utilising the tension for her advantage and preventing the two countries from joining the war against the USSR. The Germans easily foiled all these Soviet attempts.

\begin{abstract}
After concluding the Molotov-Ribbentrop Pact, the Soviet Union unexpectedly became an ally of the Slovaks. Slovak political decision-makers evaluated this act as a "historic turnaround", which then enabled the realization of mutual solidarity between Germany and Russia. Soviet diplomats characterized Slovakia in their reports as a "gate facing the Balkans" and as an "eye" into the Western half of Europe. Slovak politicians saw in their relationship with the Soviet Union the possibility to seek a counterbalance against the German influence that was encumbering the country. Slovakia's foreign policy was hoping that the Soviet Union as a Slavic brother state would support Slovakia in the Hungarian-Slovak conflict. The rivalry between Hungary and Slovakia, when both states had been attempting to gain Hitler's favour since 1939, eventually led to their attempting to win points to military domain. Thus, both of the states became ensnared in the war against the Soviet Union, an effort which other satellite states also joined. According to Jozef Tiso, Slovakia needed to enter the war against the Soviet Union because it could thus gain a basis from which to regain her territories that had been annexed to Hungary. The relationship between both states was important from the point of view of the Soviet Union foreign policy because the Soviet Union was thus able to gain information about Germany, or as the case may be, it was able to restrain them from declaring war. In the fall of 1939 full diplomatic relations between Hungary and the Soviet Union were renewed, in which the German-Soviet rapprochement also played a role. Soviet diplomats attempted to keep their government informed in as much detail as possible about the Slovak-Hungarian relationships.
\end{abstract}

109 Beneš, having realised that the Western powers did not defend Czechoslovakia at the Munich decision, regarded the USSR as the possible ally for the reconstruction of the state and for regaining his position.

110 BENEŠ, 241; ZSELICZKY, 48.

111 Edward TÁBORSKÝ, President Edvard Beneš between East and West, Stanford 1981, 183. 


\section{Keywords}

History, Diplomacy, Slovak policy, Hungarian-Russian-Slovakian relations, 1939-1941

\section{References}

Slovenský národný archív (SNA)

Slovak National Archives:

f. Ministerstvo zahraničných věcí (MZV) - Politické zprávy (PZ)

f. Národný Súd (NS)

Magyar Nemzeti Levéltár Országos Levéltára (MNL-OL)

National Archives of the Hungarian State Archives:

f. Miniszterelnökség (ME), K 28

f. Külügyminisztérium (KÜM), K 63

Slovák, 1939, Year 21, No. 227.

Slovák, 1939, Year 21, No. 234.

Slovák, 1940, Year 22, No. 107.

Slovenská politika, 1939, Year 20, No. 64.

Slovenská politika, 1939, Year 20, No. 65.

Slovenská politika, 1939, Year 20, No. 66.

ÁDÁM, Magda: Magyarország külpolitikája. Diplomáciai iratok Magyarország külpolitikája, vol. III, Budapest 1970.

BENEŠ, Edvard: Paměti. Od Mnichova k nové válce a novému vítězství, vol. 1947, Praha 1947.

ČIERNA-LANTAYOVÁ, Dagmar: Politické úvahy a súvislosti pri nadviazaní diplomatických stykov medzi Slovenskom a Sovietskym zväzom v roku 1939, in: Historické štúdie, vol. 37, Bratislava 1996, 69-87.

ČIERNA-LANTAYOVÁ, Dagmar: Pohlady na východ, Bratislava 2002.

ČIERNA-LANTAYOVÁ, Dagmar: Poznámky sovietskeho zástupcu v Bratislave k prejavom napätia medzi Slovenskom a Mad’arskom február 1940 - apríl 1941, in: Historické štúdie, 43, 2004, 237-249.

ČIERNA-LANTAYOVÁ, Dagmar: Problém vztahu s Mad'arskom v aktivitách politikov a diplomatov Slovenského Štátu 1939-45, in: Z dějín Visegrádského prostoru. Richardu Pražákovi k pětasedmdesátinám, GONEČ, Vladimír - VLČEK, Radomír (eds.), Brno 2006, 233-247.

ĎURČANSKÝ, Ferdinand: Biela kniha, vol. II., Trenčín 1991.

ĎURICA, Milan Stanislav: Dejiny Slovenska a Slovákov v chronologickom prehlade. Bratislava 1995.

FRANK, Tibor (ed.): Roosevelt követe Budapesten. John F. Montgomery bizalmas politikai beszélgetései, 1934-1941, Budapest 2002.

HILLGRUBER, Andreas (ed.): Staatsmänner und Diplomaten bei Hitler. Vertrauliche Aufzeichnungen über Unterredungen mit Vertretern des Auslandes 1939-1944, Frankfurt 1970.

HOENTSCH, Jörg K.: Základné črty ríšskonemeckej politiky voči Slovensku pred 
Salzburgom (marec 1939 - júl 1940), in: Historik v čase a priestore. Laudatio Ĺubomírovi Liptákovi, KAMENEC, Ivan - MANNOVÁ, Elena - KOWALSKÁ, Eva (eds.), Bratislava 2000, 225-252.

KAMENEC, Ivan: Trauma, Solymár 1995.

KOLONTÁRI, Attila: A Szovjetunió és az első bécsi döntés, in: Limes, 74, 2007, 2, $21-35$.

KOLONTÁRI, Attila: Magyar-szovjet diplomáciai, politikai kapcsolatok 1920-1941, Budapest 2009.

LIPTÁK, Lubomír: Príprava a priebeh salzburských rokovaní roku 1940 medzi predstavitel'mi Nemecka a Slovenského štátu, in: Historický časopis, 13, 1965, 3, 329-365.

MARIJNOVÁ, Valentina Vladimirovna: Brána na Balkán. Slovensko v geopolitických plánech SSSR a Německa v letech 1939-41, in: Soudobé dějiny, 1, 1994, 6, 827-846.

MIČIANIK, Pavel: Geopolitické postavenie Slovenska v rokoch 1939-1941, in: Politické vedy, 6, 2003, 2, 7-30.

PASTOR, Peter: A moszkvai magyar követség jelentései 1935-1941, Budapest 1992.

PEKNÍK, Miroslav (ed.): Dokumenty slovenskej národnej identity a štátnosti, vol. II, Bratislava 1998.

PETRUF, Pavol: Vztahy medzi Slovenskom a Francúzskom v rokoch 1939-1944, in: Historický časopis, 41, 1993, 5-6, 693-705.

RÁNKI, György: Hitler hatvannyolc tárgyalása 1939-1944. Hitler Adolf tárgyalásai kelet-európai államférfiakkal, Budapest 1983.

RÉTI, György: A Palazzo Chigi és Magyarország. Olasz diplomáciai dokumentumok Magyarországról a Darányi-kormány megalakulásától a szovjetunió elleni hadüzenetig, 1936-1941, Budapest 2007.

RYCHLÍK, Ján: Genéza vztáahu mocností k možnosti samostatného Slovenska či obnovy Československa, in: Slovensko na konci druhej svetovej vojny. Stav, východiská a perspektívy. Zborník materiálov zo sympózia z Častej-Papierničky 23. 11. - 25. 11. 1993, BYSTRICKÝ, Valerián - FANO, Štefan (eds.), Bratislava 1994, 114-124.

SERES, Attila: Magyar revíziós törekvések és a Szovjet külpolitika, in: Levéltári Közlemények, 71, 2000, 1-2, 79-92.

SERES, Attila: Orosz levéltári források a magyar-szovjet diplomáciai kapcsolatok történetéhez (1939), Lymbus 2005.

ŠMIHULA, Daniel: Vnútorný život na vyslanectve Slovenskej republiky v Moskve v rokoch 1939-1941, in: Historický časopis, 46, 1998, 3, 479-496.

TÁBORSKÝ, Edward: President Edvard Beneš between East and West, Stanford 1981.

The Records of the Upper House of the Hungarian Parliament. Vol. I-II, Budapest 1940-1941, 283-284 (session 22, 30 April 1940).

ZSELICKY, Béla: Kárpátalja a cseh és a szovjet politika érdekterében 1920-1945, Budapest 1998. 